\title{
Methodological Approach to Reconstructing Lost Monuments from Archaeological Findings: The San Francesco di Castelletto Church in Genoa
}

\author{
Simona Scrivano *(i), Laura Gaggero $(\mathbb{D}$ and Elisa Volpe \\ Department of Earth, Environment and Life Sciences-University of Genoa, 16132 Genoa, Italy; \\ gaggero@dipteris.unige.it (L.G.); foxy25@hotmail.it (E.V.) \\ * Correspondence: simona.scrivano@edu.unige.it; Tel.: +39-010-353-58301
}

Received: 23 August 2019; Accepted: 17 September 2019; Published: 20 September 2019

check for updates

\begin{abstract}
Throughout history, natural hazards, wars, political changes and urban evolution have contributed to the obliteration of outstanding monuments. The study of their remains, frequently recovered as archaeological findings, can be the basis for a reconstruction of the lost structures, by way of their size, function, decoration and stylistic evolution. The present study developed a multidisciplinary approach to gather and interpret archaeological fragments and archive sources, in order to gain as much information as possible on "lost monuments". The approach was tested with remnants (i.e., several hundreds of marble fragments found during archaeological excavations) of the monastic complex of San Francesco di Castelletto (Genoa), which was demolished after the Napoleonic suppressions. A preliminary organisation of the sample set was attained through cataloguing shape, size, and decoration. After this, a comparison with similar complexes still existing in Genoa allowed the inference of the age and specific ornamental functions for the majority of the pieces. Surface analysis, carried out in situ (portable microscope) and on micro-samples (petrographic analysis and SEM-EDS), allowed the characterisation of the materials (e.g., assessing marble provenance and identifying pigments). As a whole, the method evolved into an operational protocol, which helped both the organisation of the archaeological findings and the reconstruction of unknown phases of the lost monument.
\end{abstract}

Keywords: multidisciplinary approach; marble findings; Middle Ages; archaeometry; archive research; archaeology

\section{Introduction}

In the Middle Ages, the town of Genoa excelled in maritime trade across Europe, the Byzantium Empire, the Muslim world and the Far East [1]. In the XIII century in particular, Genoese merchants had important settlements in Corsica, Sardinia, along the coasts of the Black Sea and in Palestine [2]. Commerce allowed the town to grow and thrive, and each of the noble families erected palaces, churches and monastic complexes to demonstrate their power and wealth. The ramparts erected during the XI century forced the town to grow in a limited area, causing the replacement of antique buildings with new constructions over the centuries. Since the urban area was built on a hill slope, new construction usually needed to be founded on embankments to amend the acclivity; in parallel, the demolition materials from the previous buildings were employed as filling and preserved in sealed archaeological layers.

After excavation, many pieces that are representative of how Genoa appeared during the Middle Ages have been stored in the deposits of civic museums and at the local ministry agency for cultural heritage; the amount is so conspicuous as to support the definition of a "Lost City". The most 
outstanding findings are masterpieces of Middle Age sculpture (e.g., the Tomb of Margherita of Brabante by Giovanni Pisano [3]); however, the carved stone remains of the lost buildings are testament of the high ranking of the sites and represent a significant connection between the town and its European roots. A systematic approach is needed to process the recording of hundreds of pieces, in order to contextualise the findings.

Archaeometry, art history, architecture, documentary sources and geo-material characterisation equally contributed to a multidisciplinary approach, which was used to address the analysis and contextualisation of huge deposits of marble fragments [4]. The diverse disciplines, in fact, cast light on different aspects and were supported by documentary sources confirming the provenance and trade of raw materials.

The aim of this research was the investigation of two large repositories of archaeological marble fragments pertaining to the lost monastic complex of San Francesco di Castelletto (hereafter SFC) by integrated multidisciplinary analysis. The pieces had been buried since around 1822 and progressively excavated between 2003 and 2014. The methodological approach was tested in detail on a cluster of 356 white marble pieces. The integrated study of the archaeological findings was aimed at inferring parts of the decorative apparatus of the long-lost building.

\section{History of the Building}

SFC was the first Franciscan convent in Genoa; the church was erected between 1250 and 1302 in the Tyrrhenian gothic style. A drawing (enclosed in the XVIII century manuscript Epitaphia, sepulcra et inscriptiones cum stemmatibus marmorea et lapidea existentia in ecclesis genuensibus, by Domenico Piaggio), testifies that, throughout the centuries, the striped façade was characterised by the typical black and white alternation of dimension stone blocks of white Carrara marble and a calcareous marlstone called Pietra di Promontorio (Figure 1).

The whole complex was bombed in 1505 during the siege of the city by the French army, and in 1522 it was ransacked by the Spanish army [5]. During the early XVI century, the building deteriorated and needed restoration works, which were undertaken after the Council of Trent. Architectural novelties were introduced following the Counter-Reformation. Between 1581 and 1586, the interior of the building was renewed in a baroque style, side chapels were introduced along the left hand side, and the apse and transept areas were completely remodelled [6]. The last great intervention in the building was the introduction of the so-called Tribuna del Principe (1602), a structure on the left hand side of the transept allowing the members of the Doria family to directly access the church from their palace (i.e., Palazzo Tursi) [7].

After the Napoleonic suppression of religious orders (1789), the church was demolished and partially incorporated into residential buildings. The demolition was carried out over a period of 15 years, in several phases, following a demand for new space for the gardens of the neighbouring noble households [8]. At first, the nave was partly demolished and partly encased in new buildings, then the transept area was dismantled along with the façade, and the remnants were interred to fill the crypt and the subterrain, to allow the expansion of the nearby Palazzo Tursi.

The area where the SFC church was once erected is now a terraced, visitable garden, preserved as a connection path between the Palazzo Bianco civic museum and Palazzo Tursi. In 1892, a corridor was erected where the left portion of the transept and part of the crypt once stood, in order to provide a sheltered passage between the two parts of the museum. From 2003 to 2004, this passage was renewed with the addition of an elevator, and during the following excavations several hundred ornamental marble fragments were recovered and identified with an inventory number by the local Superintendence. The latter is composed of the acronym of the finding place followed by the excavation year and the stratigraphic unit (SU) number, and then numbered in sequence (e.g., a piece found in the SU 300 of the gardens of Palazzo Tursi during excavations in 2003 could be catalogued as GPT'03 300-1) [9]. 


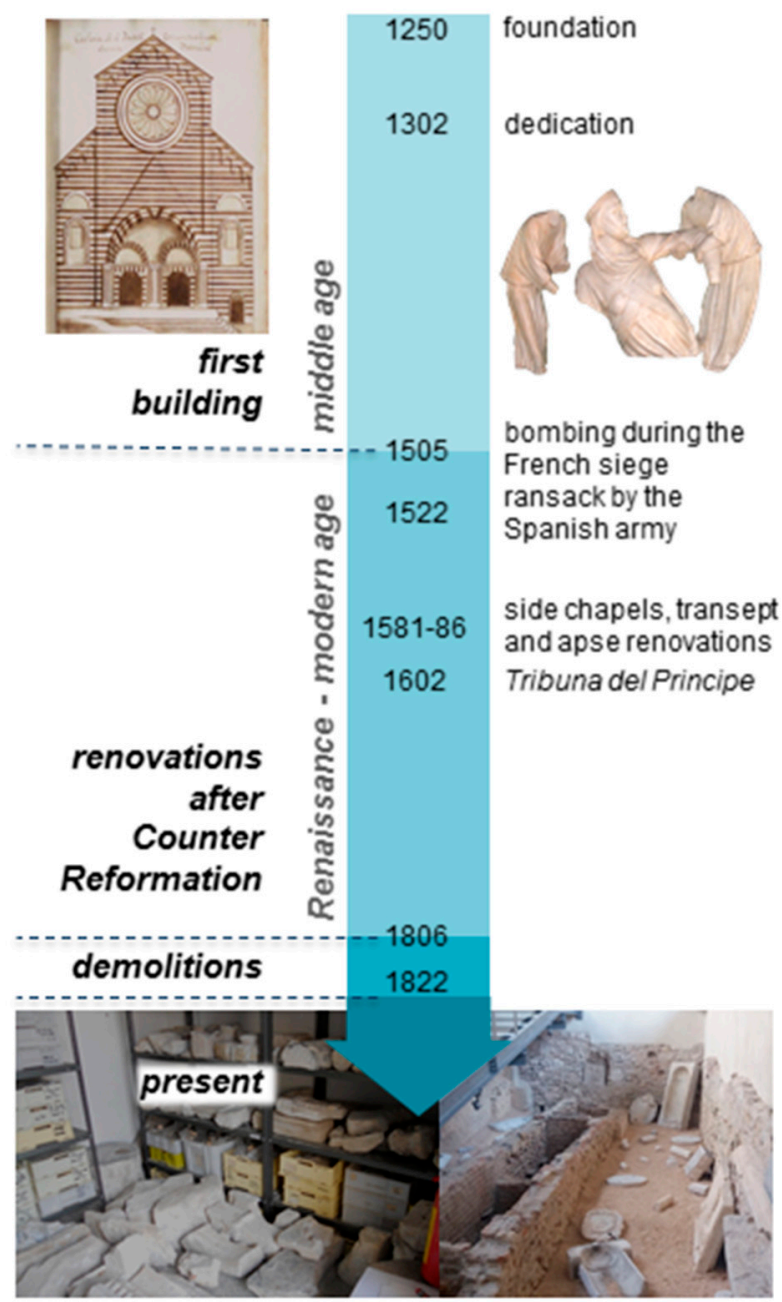

Figure 1. Timeline indicating the major events involving the long-lost monastic complex. Its three main life phases (construction, renovations, dismantling) are evidenced. Photographic reproduction of the drawing of the façade, courtesy of the Berio Library, Genoa, and photography of the repository, courtesy of the Superintendence of Archaeology, Fine Arts and Landscape for the metropolitan city of Genoa and the provinces of Imperia, La Spezia and Savona (partial or total reproduction is forbidden without prior (written) permission).

\section{Methods}

The analytical protocol encompassed several phases to gather information about the monastic complex, the decorative apparatus of the Middle Ages, and the typology and amount of fragments.

\subsection{Implemented Catalogue Sheets}

The first step of the analysis was to describe and further implement the catalogue of the 356 marble pieces. For the purpose of this study, pieces without an inventory number were assigned a code composed of the repository acronym and a sequential number (e.g., a piece of the San Francesco da Paola repository could be numbered SFP 01). For the catalogue of the fragments, a filing card was designed to gather physical and historical artistic data for each piece. In particular, the fragment size, material, form and typology, presumed age and surface characteristics (e.g., signs of utensils, paint layers, decay features) were annotated. The dataset was completed by scaled photography of each piece. The image acquisition was carried out by a compact camera. 


\subsection{Study of Similar Buildings: Reconstruction of the Functions}

Since the fragmentary nature of the pieces prevented an unequivocal interpretation of their function and, therefore, their location inside the building, a comparison with several existing monuments (of analogous function and/or age) was carried out. The monuments selected for this comparison were the churches of San Lorenzo, Sant'Agostino and San Matteo in Genoa, and San Salvatore and San Fruttuoso in Cogorno and Camogli, respectively. The Doria and municipal palaces in Genoa were also compared. All of these buildings were erected between the XIII and XIV centuries and still preserve the typical features of the Tyrrhenian gothic style.

\subsection{Bibliographic Research}

Extensive bibliographical research was undertaken to produce a more complete image of the historical evolution of the complex and its relationship with local history. In fact, although the monastic complex had great importance throughout the centuries, its history is, in part, obscured. Detailed research was carried out at the State Archive, where several documents concerning the lost building are preserved. Old maps and blueprints, along with drawings and catalogues, were studied to gather information about the architecture (both construction and demolition phases) and the ornamental apparatus through the centuries. The archive research was also extended to the Caratorum Occidentis and the Caratorum Orientis (i.e., registers of goods arriving in the harbour of Genoa during past centuries) and a series of notary documents of marble trading in the State Archive of Massa Carrara.

\subsection{Archaeometric Analysis}

The fragments were investigated from a materials point of view, in particular the surface finishing and the marble itself. Four micro-samples (about $1 \mathrm{~mm}^{2}$ ) of multicoloured pictorial layers and little marble fragments detached from one of the findings were analysed. The first were mounted on a stub with conductive tape and a graphite sputter coated for Scanning Electron Microscopy with Microanalysis (SEM-EDS). The marble fragment was partly embedded in resin to obtain a thin section to be analysed with a petrographic microscope (Leitz Laborlux 11 POL microscope coupled with a 5M pixel OptikamB5 digital camera; microscope: ZEISS, Thornwood, NY, USA; camera: OPTIKA s.r.l., Ponteranica, Bergamo, Italy) and partly mounted on a stub with conductive tape and a graphite sputter coated for SEM-EDS analysis. All SEM-EDS analysis were carried out with a Tescan Vega 3 LM SEM, equipped with an Apollo $X$ detector and a Microanalysis TEAM energy dispersive system (EDS) (SEM/EDS: TESCAN, Brno, Czech Republic). The work was undertaken at the Department of Earth, Environment and Life Sciences of the University of Genoa. In particular, the petrographic analysis of marble encompassed image analysis with Image ${ }^{\circledR}$ software in order to recast the maximum grain size (MGS) and the grain orientation on a surface of about $1.5 \mathrm{~cm}^{2}$.

\section{Results}

\subsection{Implemented Catalogue: Data Analysis}

The data collected in the catalogue sheets were compared and analysed in order to obtain statistics referring to the relative abundance of pieces from the Middle Ages and their main features (Figure 2). A large portion of the catalogued pieces were too fragmentary to be stylistically attributed to a period of edification of the church (47.5\%), while many of the identifiable pieces could be collocated throughout the Middle Ages (40.4\%), and only $12 \%$ pertained to the renovations of the late XVI and early XVII centuries (Figure 2A). Among the pieces, $48.6 \%$ had decorative function, while about a fourth had diverse architectonic functions (pillars, columns, blocks, slabs, etc.), and the remaining $25.3 \%$ were excessively fragmented to be interpreted (Figure 2B). 


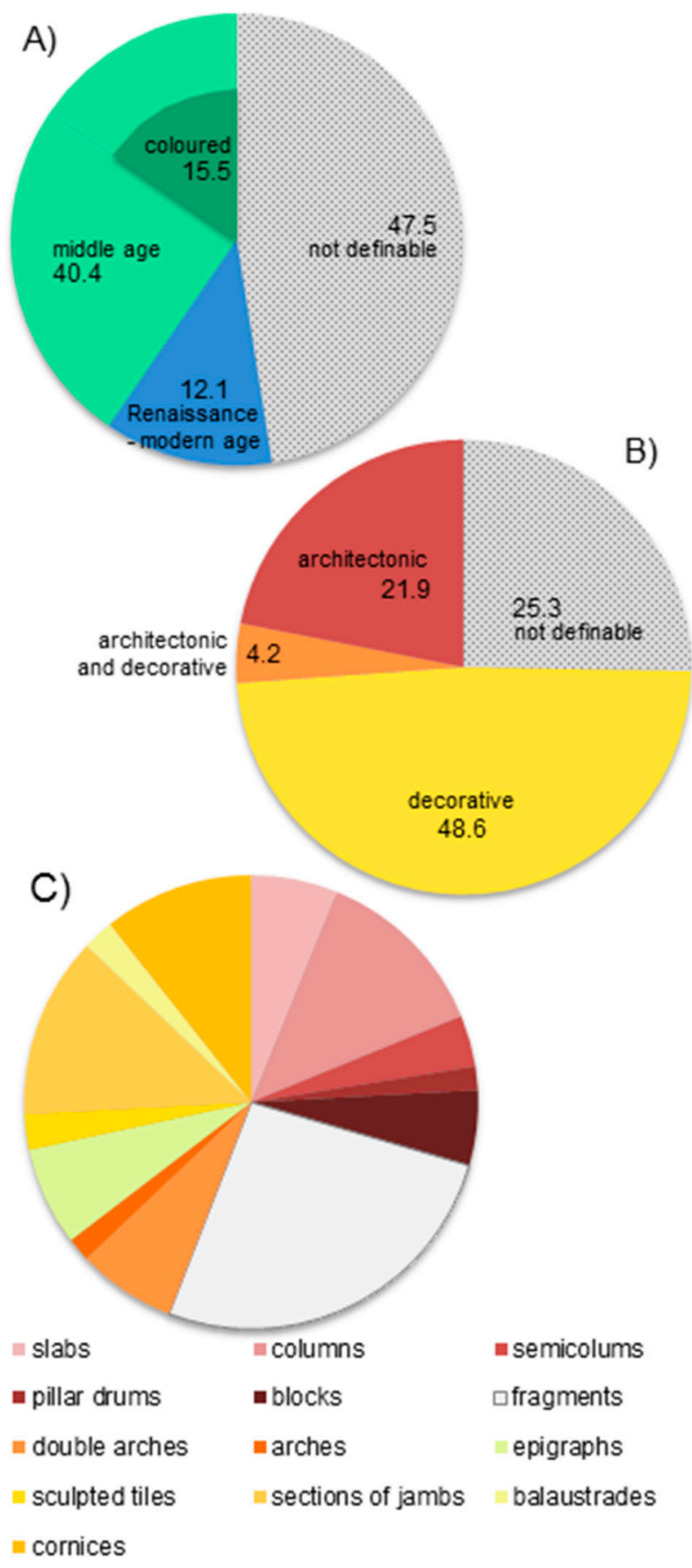

Figure 2. Data analysis. Pie charts showing stylistic and functional data for the 356 fragments. (A) Clusters by main epoch, with specification of coloured pieces within medieval fragments. The fragmentation of half of the pieces makes them difficult to date. The majority of the construable pieces pertain to the medieval edifice. (B) Clusters by function. Half of the pieces had decorative function. Fragmentary pieces were counted as not definable. (C) Clusters by object typology.

Among the (Middle Age) pieces, 37.5\% showed remains of white preparation or pigments (Figure 2A). These 54 pieces preserved painted layers and are both architectonic and decorative pieces, with a prevalence of the latter. The remnants of pictorial layers are usually fairly widespread and made of intense primary colours: red, blue and yellow. A few architectonic pieces also presented green pictorial layers. The surface of the majority of the pieces also preserved evidence of carving tool marks. 
Blocks and columns mainly displayed signs of bush hammer and tooth chisel, while the decorative pieces largely presented fine details made with point and hand drill.

\subsection{Inferring the Function: Typological Grouping}

The morphological and dimensional analyses were the basis for recognising the original function of the majority of the pieces, reinforced by the comparison with similar buildings. The 356 marble fragments were organised in clusters according to nature and function (e.g., architectonic or decorative) and further subdivided by presumed age and size, to reconstruct the actual use of the fragment in the building (Figure 2C).

Of the pieces with a recognisable function, the 99 architectonic pieces were divided into rough-hewn blocks, slabs, columns and pillars. Sixteen out of nineteen rough-hewn blocks were made from bigger marble pieces to build a wall in the corridor area during the XX century, while the surface treatments on the remaining three suggest that they were employed as dimension stones in the Middle Age edifice. In the cluster of slab-shaped pieces, 22 were interpreted as architectonic pieces with different functions. For their dimensions and outline, 17 items were catalogued as paving slabs (of at least two different tile sets), both of squared tiles, arranged at an angle of $45^{\circ}$ but with different edge lengths $(18.5 \mathrm{~cm}$ and $24.5 \mathrm{~cm}$ ), and probably framed by marble listels. The other five slabs presented a polished surface and one rounded edge, and were interpreted as step treads, probably belonging to two different sets of stairs due to their different thicknesses $(4 \mathrm{~cm}$ and $10 \mathrm{~cm})$.

The vertical support pieces include six segments of semi-pillars, nine segments of semi-columns, four segments of angular columns and 39 small columns. The segments of semi-pillars are prisms, with an irregular polygonal base, simulating an octahedral pillar. As for the segments of semi-columns, two series were inferred from the difference in diameter: five segments with a diameter of about $26 \mathrm{~cm}$ comprise the first group, while the second group is made of four fragments with diameters wider than $45 \mathrm{~cm}$, probably in accordance with the semi-columns still in place forming the cruciform pillars that once carried the lantern. A series of fragments of column segments (four pieces) is made up of hollow blocks with a horseshoe-like shape, probably used to simulate a corner column or a semi-column with a diameter wider than $40 \mathrm{~cm}$. The last cluster in this category is made of 39 small columns, further subdivided in a series with different diameters: $8 \mathrm{~cm}$ (five fragments); $9 \mathrm{~cm}$ (six fragments); $10 \mathrm{~cm}$ (nine fragments); $11 \mathrm{~cm}$ (nine fragments), $12 \mathrm{~cm}$ (five fragments); $13.5 \mathrm{~cm}$ (three fragments); and $15 \mathrm{~cm}$ (two fragments). Actually, the proportions are not completely reliable when reconstructing the function because both the handmade manufacturing process and subsequent weathering processes can alter the size of a single piece and its attribution to a group. Only the signs of anchorage helped in inferring their function: anchorages along the trunk suggest a location along a wall (see the remnants of one of the cloisters in Figure 3B), while fixings on the bottom or top surfaces suggest an isolated column, coupled with capitals and basis. 


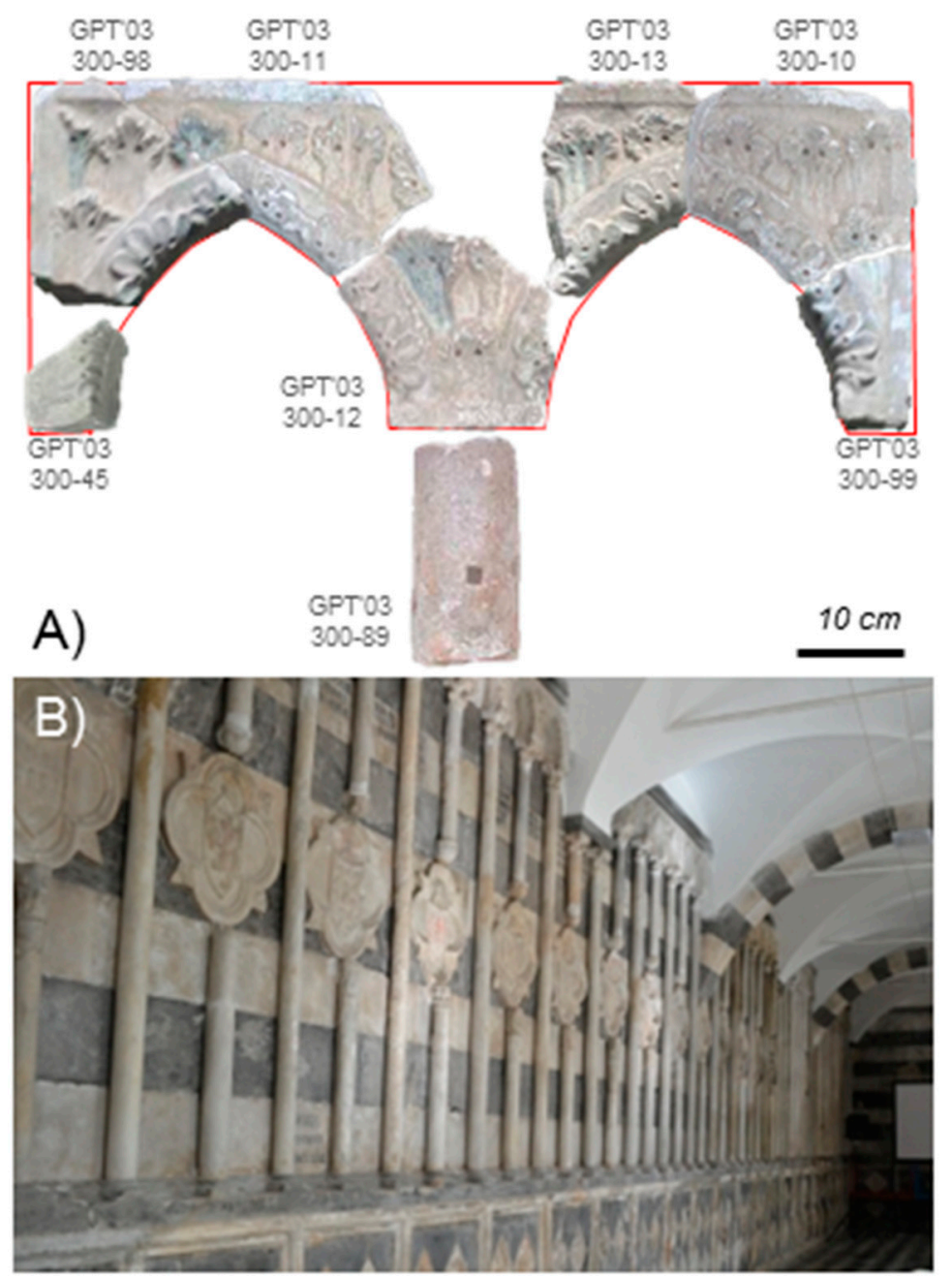

Figure 3. Function reconstruction through comparison with other parts of the building that are still intact. (A) Virtual reconstruction of one of the double arches from seven pieces (GPT'03 300-10, -11, -12, $-13,-44,-98,-99)$ and one of the columns with anchorage signs on the back of the trunk (GPT'03 300-89). The photography of the fragments is courtesy of the Superintendence of Archaeology, Fine Arts and Landscape for the metropolitan city of Genoa and the provinces of Imperia, La Spezia and Savona (partial or total reproduction is forbidden without prior (written) permission). (B) Remains of the ambulacrum of the lower cloister characterised by a series of double arches and columns embodied in the wall, now part of the elementary school Daneo.

It was also possible to reconstruct the function of 173 decorative pieces, grouped as: sculpted tiles, decorated slabs, balustrade pieces, capitals and column bases, bass relief arches, double arches, pointed arches, cornices and decorative mouldings. Since ornate fragments bear distinctive traces of manufacturing, they can easily be matched to infer one former piece. For instance, four out of the nine sculpted tile fragments were easily related back to two sculpted tiles (Figure 4A,B) and a pair of tiles with the same dimensions and manufacturing process, probably with one function. 

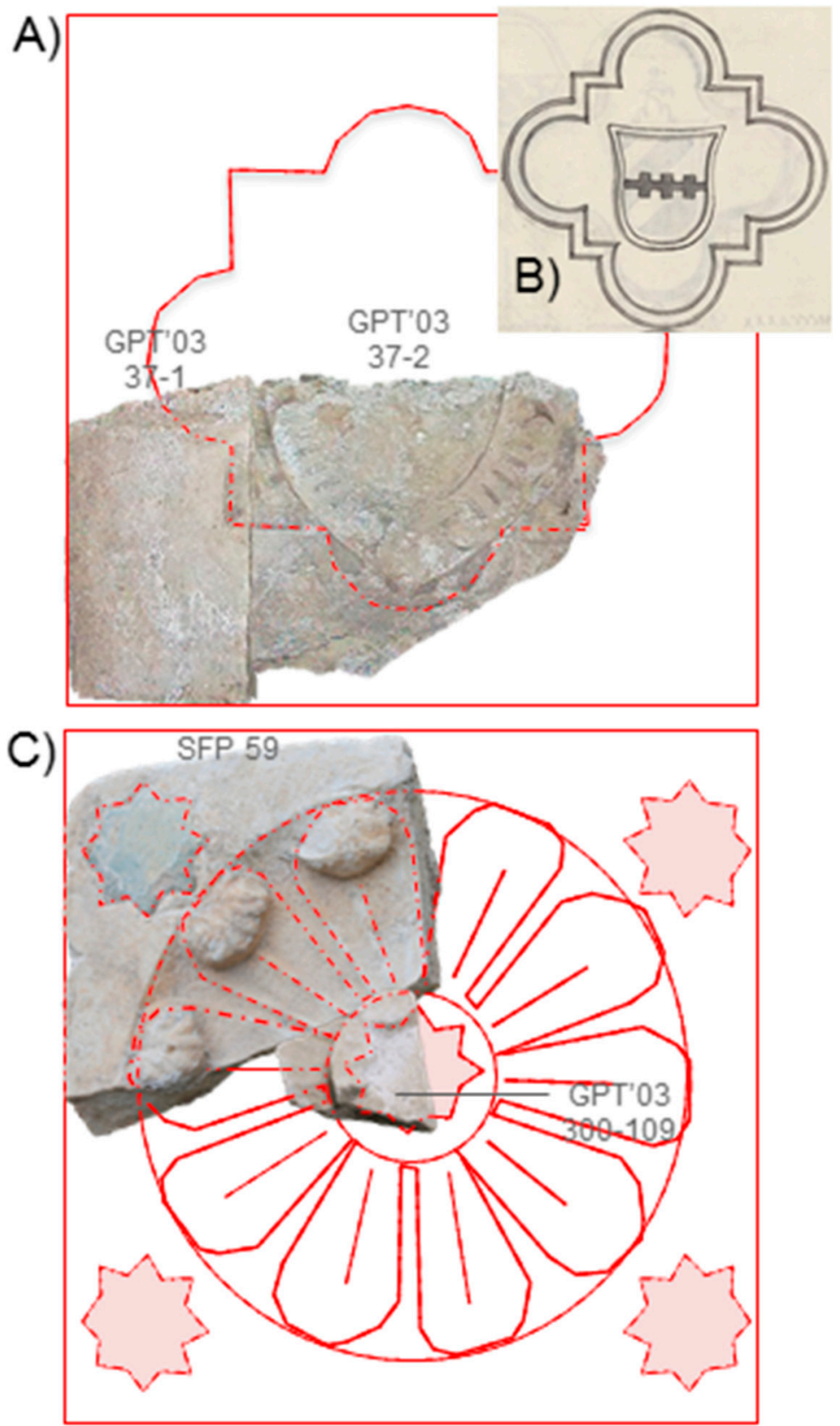

Figure 4. Reconstruction of sculpted tiles. (A) Entombment sculpted tile reconstructed joining the two fragments GPT'03 37-1 and GPT'03 37-2. The photography of the fragments is courtesy of the Superintendence of Archaeology, Fine Arts and Landscape for the metropolitan city of Genoa and the provinces of Imperia, La Spezia and Savona (partial or total reproduction is forbidden without prior (written) permission). (B) One of the drawings of the manuscript Epitaphia, sepulcra et inscriptiones cum stemmatibus marmorea et lapidea existentia in ecclesis genuensibus, by Domenico Piaggio, with an aspect similar to tile a), folio 36. Photographic reproduction courtesy of the Berio Library, Genoa. (C) Floral sculpted tile with inlays resulting from the merging of the two fragments GPT'03 300-109 and SFP 59. The photography of the fragments is courtesy of the Superintendence of Archaeology, Fine Arts and Landscape for the metropolitan city of Genoa and the provinces of Imperia, La Spezia and Savona (partial or total reproduction is forbidden without prior (written) permission).

Another example is an inlaid slab, probably from a side altar, which was partly reconstructed by combining three pieces. Also, among the 25 fragments of epigraphic slabs, nine pieces contributed to reconstruct four inscriptions, probably connected to wall or paving entombments. A cluster of 10 slabs, 
mainly decorated with helmets and heraldic shields, which are usually coupled with inscriptions to mark eminent burials, supports this function attribution. Another set of fragments is the ornate double arches, probably part of the cloister decoration. Within the 25 fragments belonging to this group (variably decorated with polychrome phytomorphic patterns such as leaves, flowers and raceme), 17 helped in reconstructing five double arches (Figure 3A), while only eight were not paired to compose a whole piece.

A small cluster of six pieces with similar shapes was subdivided into two groups: (a) the ogive arches, sculpted on both sides and probably used in arched windows (three pieces), and (b) the bass relief arches, i.e., decorative blocks once inserted in the masonry to mark the entombment of a noble household (three pieces). Five single column bases and two capitals (as well as one double base and one double capital) were catalogued, probably linked to the ornate double arches or the arched windows. These nine pieces have a uniform style and size, corresponding to a $10 \mathrm{~cm}$ diameter column.

A group of 46 fragments of decorative mouldings with octagonal sections (with four smoothed, decorated sides and alternate straight and convex profiles) presented different superficial treatments. The majority of these pieces present a slightly rounded line, which suggests that they were used as sections of jamb of arched portals or ornaments of arched or rose windows. They have a series of eight different decorative patterns (i.e., smoothed faces, knots, flowers, diamond points, shells, and different types of leaf) and three different sizes of octagonal base: $8 \mathrm{~cm}$ (five pieces), $11.5 \mathrm{~cm}$ (14 pieces), and about $15 \mathrm{~cm}$ (27 pieces). Subdivision by dimension can be due to the diverse function or to the fact that some of the pieces showed a difference in size between opposite ends, suggesting a general thinning of the higher elements of the jamb sections.

Thirty-eight fragments of cornices mainly pertain to modernisation in the XVII and XVIII centuries. These pieces were probably employed on ornate side chapels and altars. Eight pieces of balustrade probably also belong to the same phase and decorative program.

\subsection{Bibliographic and Archive Research}

Bibliographic research was fundamental to reconstructing the history of the construction phases of the church, as delineated in paragraph 2.

The manuscript Epitaphia, sepulcra et inscriptiones cum stemmatibus marmorea et lapidea existentia in ecclesis genuensibus, by Domenico Piaggio, helped with the interpretation of 10 of the epigraphic slab fragments, therefore allowing the correct time framing and collocation inside the complex (Figure 5A,B). Moreover, archive research helped identify the primary source of white marble in the Carrara district. In fact, early documents from the late XII and early XIII centuries state that Carrara, still under the archbishopric of Luni, traded marble with Genoa. This is, in particular, demonstrated by contacts between marble quarries in Carrara and warehouses in the Harbour of Genoa for the commerce of pre-worked pieces (i.e., columns and capitals [10]). Furthermore, a trade document, recovered from the State Archive of Genoa, proved the procurement of white Carrara marble during the last building phase of the church (the edification of the Tribuna del Principe). 

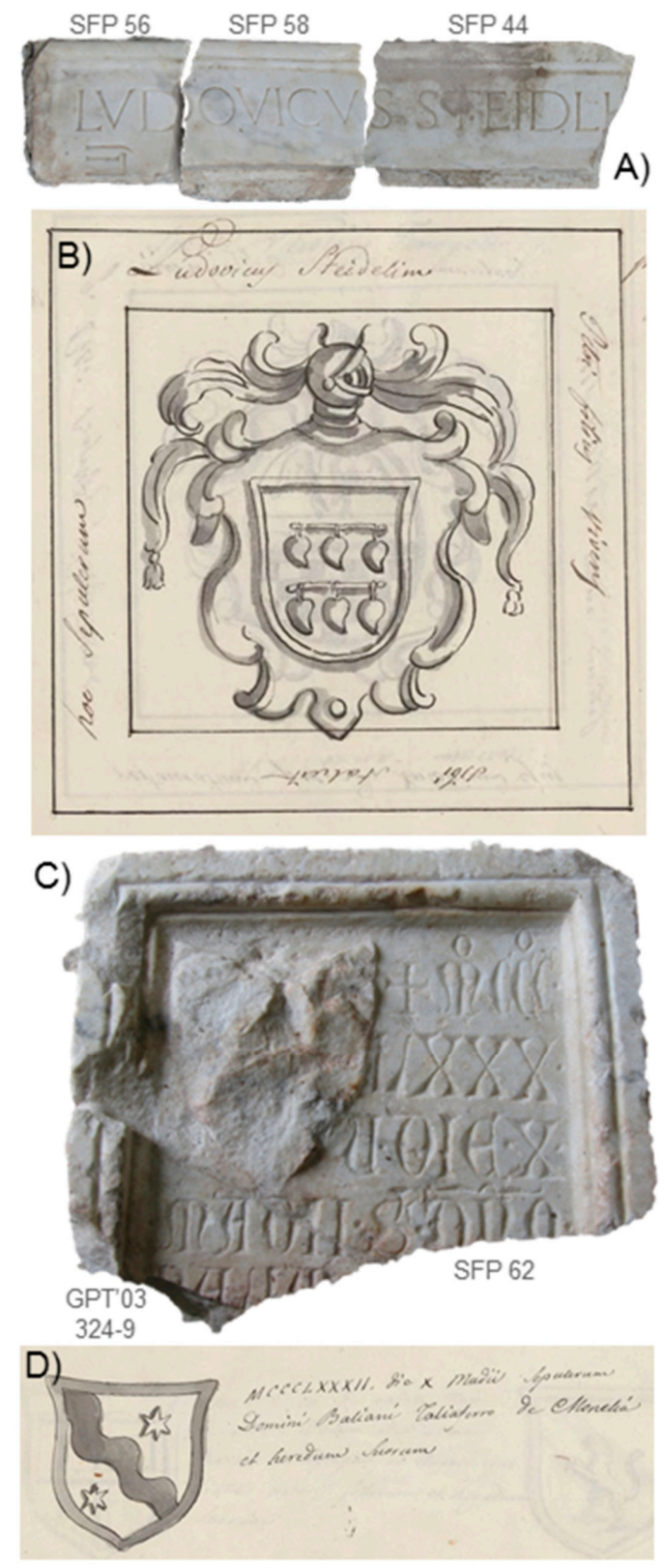

Figure 5. Function reconstruction by comparison with archive sources. (A) Epigraph (SFP 44, 56 and 58) reading "LIJ LUDOVICUS STEIDL". Photography of the fragments is courtesy of the Superintendence of Archaeology, Fine Arts and Landscape for the metropolitan city of Genoa and the provinces of Imperia, La Spezia and Savona (partial or total reproduction is forbidden without prior (written) permission). (B) Corresponding drawing inside the manuscript Epitaphia, sepulcra et inscriptiones cum stemmatibus marmorea et lapidea existentia in ecclesis genuensibus, by Domenico Piaggio, folio 222. The manuscript places the epigraph "prope Cappellam Assumpte", meaning near Assunta Chapel. Photographic reproduction courtesy of the Berio Library, Genoa. (C) Epigraph (GPT'03 324-9) reading "+ MCCC(L)XXX(II) DIE X MADII S DNO (B)A". The photography of the fragments is courtesy of the Superintendence of Archaeology, Fine Arts and Landscape for the metropolitan city of Genoa and the provinces of Imperia, La Spezia and Savona (partial or total reproduction is forbidden without prior (written) permission). (D) Corresponding drawing inside the manuscript Epitaphia, sepulcra et inscriptiones cum stemmatibus marmorea et lapidea existentia in ecclesis genuensibus, by Domenico Piaggio, folio 14. The manuscript does not provide a location inside the complex, but since it is in the first pages, the most probable location is the façade. Photographic reproduction courtesy of the Berio Library, Genoa. 


\subsection{Archaeometric Analyses}

\subsubsection{Pigments}

Pigments collected from diverse Middle Age pieces were analysed in situ by optical microscopy, collecting data on size and relative distribution of pigment particles in the pictorial layer. The study was deepened by means of SEM-EDS analysis [11]. Microanalysis evidenced that blue areas correspond to copper carbonate (Figure $6 \mathrm{~A}, \mathrm{~B}$ ). The red layers are made of a mixture, rich in iron, silica and aluminium (Figure 6C,D). The green paint traces are composed of a silica-aluminate that is variably rich in iron, magnesium, potassium and sodium (Figure 6E,F). The yellow pigment is a lead-based product (Figure 6G,H). Subsequent $\mu$-Raman (Horiba Jobin-Yvon Explora_Plus) and FT-IR spectroscopy (Spectrum 65 FT-IR spectrometer with a diamond attenuated total reflectance (ATR) device) analysis confirmed azurite as the main component of blue paint layers, red ochre for the various shades of red, green earths for green areas, and massicot for yellow traces [11]. Scrivano et al. [11] analysed in detail the paint relics, aiming at reconstructing the Middle Age art supply market and paint techniques.

\subsubsection{Marble}

The bibliographic data relating to medieval trade were verified by analysing a fragment of white marble detached from one of the decorative arches, stylistically dated to the XIV century (GPT'03 300-3; Figure 7A). The thin section (Figure 7B) shows a maximum grain size (MGS) of $0.6 \mathrm{~mm}$ and an average grain size (AGS) of $0.2 \mathrm{~mm}$, a locally heteroblastic, weakly anisotropic, granoblastic texture with lobate-indentate grain boundaries. Accessory minerals such as muscovite and pyrite occur. SEM-EDS analysis on a fragment showed Mg traces in calcite. Grain size analysis is compatible with four quarrying districts: Carrara, Afyon (Docimium), Göktepe, and Athens (Hymettos). According to the literature [12], Hymettos marble is characterised by the presence of porphyroblasts, and Docimium marble presents strain features, and therefore they are not compatible with the studied sample. Also, trace elements are reported as useful in identifying marble provenance [13]; in this case, the absence of $\mathrm{Sr}$ characterising Göktepe marble contributes to the exclusion of this extraction district. The whole archive and historical data, textural data, MGS, and microanalysis suggest that the fragment is compatible with lithotypes extracted in the Carrara district (Figure 7C) [12,14-18]. 


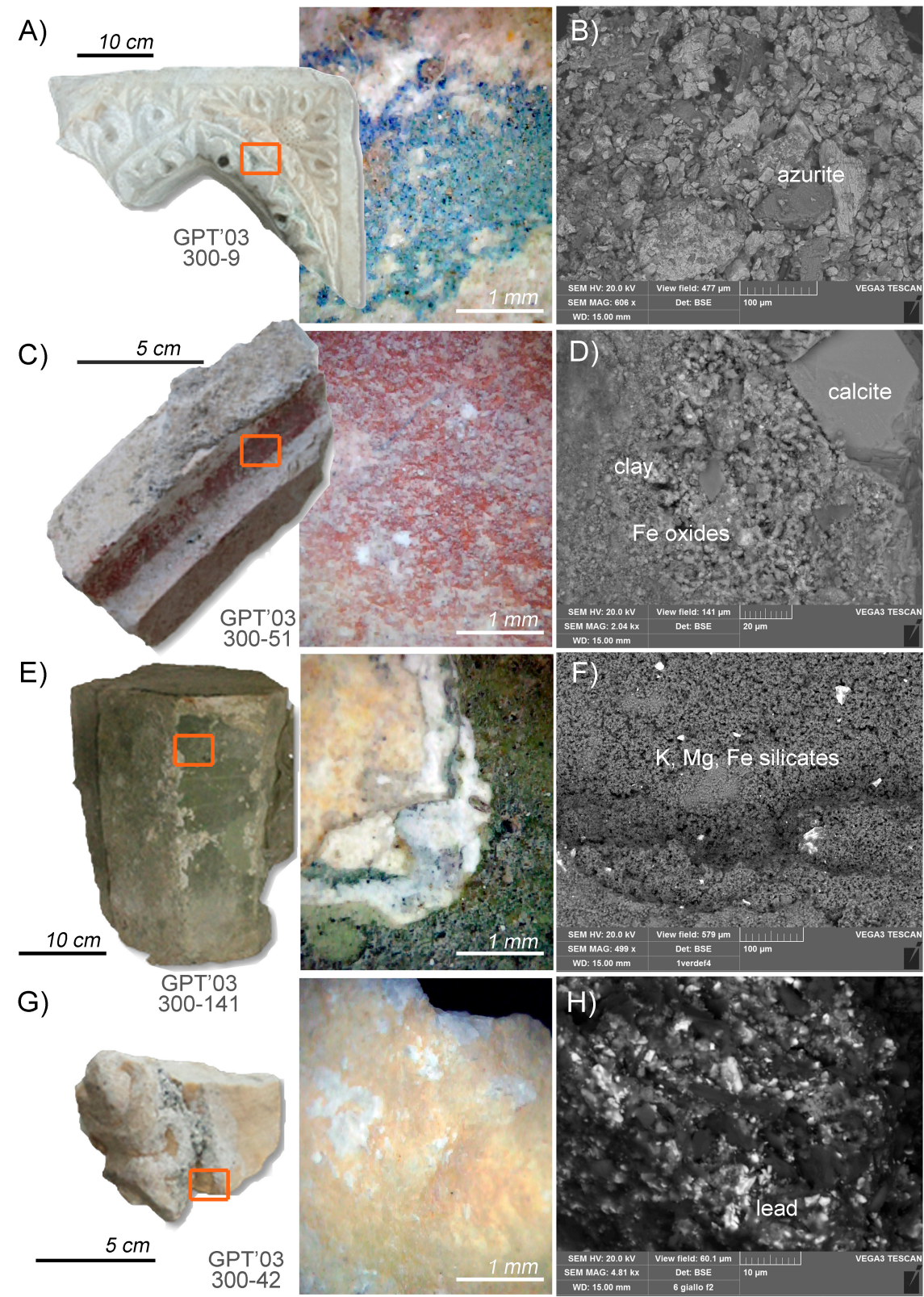

Figure 6. Analyses of paint traces. (A) Blue. Macrophotography of GPT'03 300-9 and close-up of its surface. Darker pigment particles can be seen in the light blue background. (B) Blue. SEM microphotography. Light grey corresponds to copper carbonates, while darker tones are characteristic of the pictorial medium (oil + proteinaceous material). (C) Red. Macrophotography of GPT'03 300-51 and close-up of its surface. The fine grinding of the pigment impedes the recognition of its morphology. (D) Red. SEM microphotography. The lighter rounded microparticles correspond to Fe-oxides and are the main factor responsible for the colour. (E) Green. Macrophotography of GPT'03 300-141 and close-up of its surface. A multi-layered finishing can be seen, where the external layer is characterised by a light green colour, where darker irregular particles can be seen. (F) Green. SEM microphotography. The area analysis showed the presence of $\mathrm{K}, \mathrm{Mg}$, and Fe silicates. (G) Yellow. Macrophotography of GPT'03 300-42 and close-up of its surface. The fine grinding of the pigment impedes the recognition of its morphology. (H) Yellow. SEM microphotography. Lighter particles, dispersed in organic matrix (dark grey), present a lead oxide spectrum. Photography of the fragments is courtesy of the Superintendence of Archaeology, Fine Arts and Landscape for the metropolitan city of Genoa and the provinces of Imperia, La Spezia and Savona (partial or total reproduction is forbidden without prior (written) permission). 

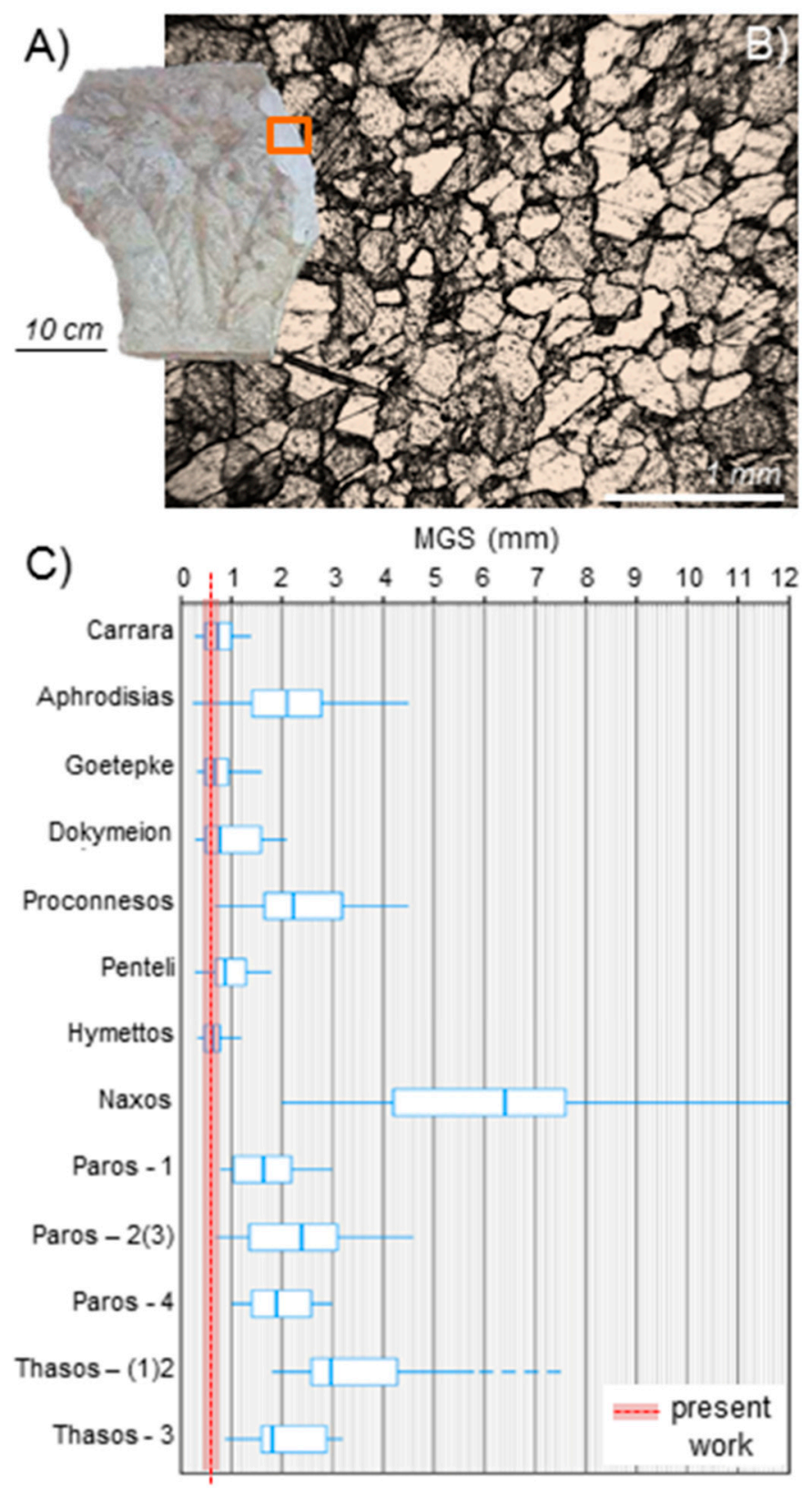

Figure 7. Marble characterisation. (A) Macrophotography of the fragment GPT'03 300-3, courtesy of the Superintendence of Archaeology, Fine Arts and Landscape for the metropolitan city of Genoa and the provinces of Imperia, La Spezia and Savona (partial or total reproduction is forbidden without prior (written) permission). (B) Microphotography, crossed polars. The marble is homeoblastic, organised in a granoblastic texture, with low-grade anisotropy and linear to lobate grain boundaries. (C) Comparison between maximum grain size (MGS) values of the white marbles most diffused in ancient times (graph modified from Antonelli and Lazzarini [11]). The red dotted line presents the mean MGS value of the sample from the present study, and the red area corresponds to the Gaussian curve of the measured MGS values.

\section{Discussion}

The typological subdivision obtained by visual and functional analysis allows for the hypothesis that the majority of the pieces derive from the dismantling of the façade of the church (e.g., double arched windows, segments of jambs of arched portals, rose and double arch windows), of at least one of the cloisters (e.g., ornated double arches, columns), of the sacristy (e.g., epigraphs) and of side chapels 
in the transept area (e.g., cornices and balaustrades). Moreover, the fact that the pieces belonged to different structures is corroborated by a direct comparison between the epigraph fragments and the manuscript Epitaphia, sepulcra et inscriptiones cum stemmatibus marmorea et lapidea existentia in ecclesis genuensibus, by Domenico Piaggio. The stylistic attribution of the pieces to diverse construction phases, along with the archive research, confirms that the façade and the cloisters preserved their Middle Age aspect throughout the centuries, while the transept area was largely reworked during the XVII and XVIII centuries.

In particular, after comparison with the two front drawings and the appearance of other coeval churches, it was possible to hypothesise that the fragments pertaining to arched windows and jamb sections were part of the decoration of the façade (Figure 8). The series of double arches with one sculpted side and the small columns with anchorage on the trunk were part of the wall decoration of one of the cloisters, as testified by remnants of the monastic complex, which are, at present, incorporated in XIX century residential buildings (Figure 3B). The presence of decorated keystone slabs, along with a series of small columns of various diameters, and the variety of heraldic sculpted tiles suggests the presence of arcosolium tombs within the complex, similar to the Doria Abbey in San Fruttuoso (Camogli, Genoa). The presence of various kinds of cornices, the balustrade pieces and the quality of the decoration of the entombment slabs confirms the high rank of the side chapels in the transept area (i.e., Tribuna del Principe and the Grimaldi chapel).

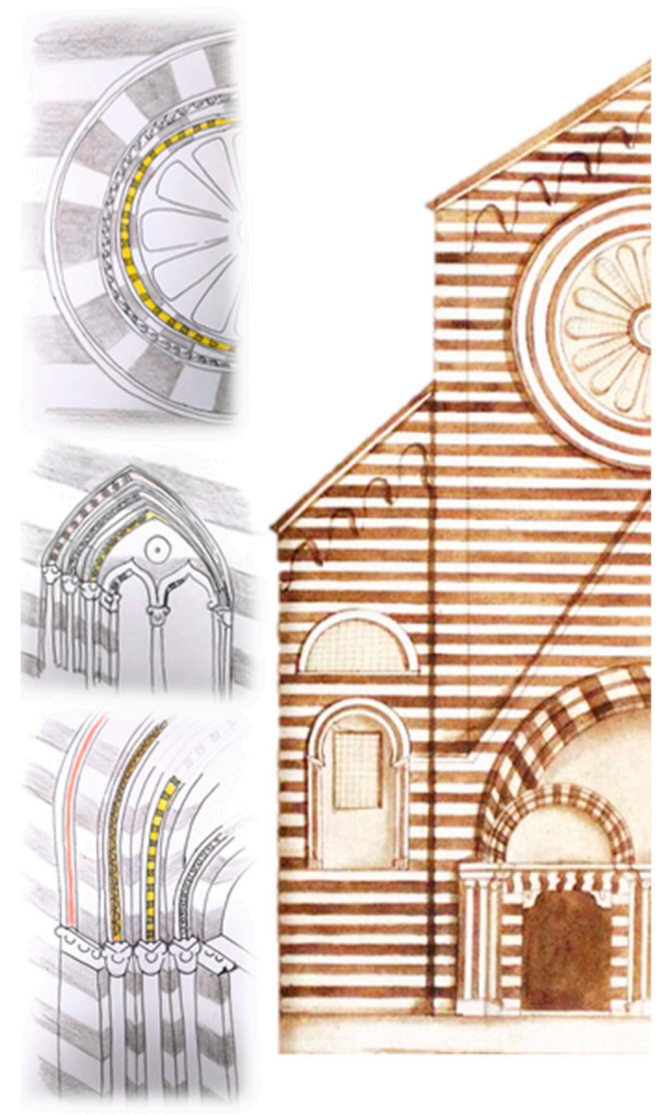

Figure 8. Inferred appearance of the façade, according to the data that emerged in the present study. On the left side, reconstructions of the decorative reliefs of a rose window, double arched windows and a splayed portal, and their colours. The possible positioning of the analysed fragments on the façade, along with its chromatic scheme, based on the paint relics is rendered with three virtual models. On the right hand side, for comparison, a reproduction of the drawing of the façade from the manuscript Epitaphia, sepulcra et inscriptiones cum stemmatibus marmorea et lapidea existentia in ecclesis genuensibus, by Domenico Piaggio, folio 12, courtesy of the Berio Library, Genoa. 
Whilst there is a good match between the series of semi-columns and the remnants in the gardens of Palazzo Bianco, the segments of octagonal semi-pillars do not find a comparison with other coeval churches of the same period, but only in public or private buildings. This probably indicates a most probable origin in the cloister.

The typological grouping highlights the complexity of the decorative apparatus, both in terms of ornamental motifs and colours. The presence of paint traces on a large portion of marble fragments from the Middle Ages (linked to both indoor decorations and outdoor architectural ornaments, such as arched portals or windows; Figure 8) suggests that during the Middle Ages the whole complex of church and monastery had a colourful aspect, both inside and out. The polychromy inferred from paint remnants on the marble fragments is supported by the analysis of coeval monuments, e.g., the San Lorenzo Cathedral, whose façade was once enriched by ceramics, enamels and paint [19]. The brilliant hues were not meant to achieve a naturalistic portrait but were aimed at an estrangement to highlight the transcendence of the building. Another hint pointing to a polychrome appearance is represented by the stratified remnants of coloured mortars adherent to the basis of the cruciform pillars still in place in the gardens of Palazzo Bianco, which once carried the ceiling of the transept area.

Moreover, the surfaces of the blocks and columns show signs of bush hammer and tooth chisel, similar to those found in other coeval monuments, and it is inferred that this technique was used to highlight the surface or to secure a better adhesion to plasters for fresco decorations.

Notably, the amount of white marble pieces testifies a thriving market during the Middle Ages, in spite of sporadic archive records.

\section{Conclusions}

On the whole, our multidisciplinary approach to the study and characterisation of a cluster of 356 marble fragments, $40 \%$ of which is ascribed to the Middle Age phase of the monastic complex, enabled:

- the recognition of the structural or decorative function of most pieces;

- the unravelling of the primary source of the marble from the Carrara district;

- the deduction of the aspect of the monument. In particular, compared with the churches of San Lorenzo, Sant'Agostino and San Matteo in Genoa, and San Salvatore and San Fruttuoso in Cogorno and Camogli, the SFC church preserved throughout time its medieval façade with a central double splayed portal, even if the double arched windows were probably plugged during the XVII century renovations;

- the obtainment of insights into the decoration of Middle Age monuments in Genoa. This aspect suggests that decoration patterns were shared or produced by a restricted number of sculpture ateliers;

- the inference, on the whole, of an organic, historic reconstruction of the monument before its demolition.

In conclusion, the organisation of the fragments with a typological approach, in clusters based on appearance, dimensions and function (deduced from both material data and manuscripts), allowed at least a partial reconstruction of the coloured aspect of the façade to be achieved (Figure 8).

Author Contributions: Conceptualisation, E.V., S.S. and L.G.; methodology, S.S. and L.G.; validation, S.S. and L.G.; investigation, E.V. and S.S.; resources, L.G. and S.S.; data curation, S.S. and E.V.; writing-original draft preparation, S.S. and L.G..; writing-review and editing, S.S. and L.G.; supervision, L.G.; funding acquisition, L.G.

Funding: This research benefited from the financial support of the "Analisi delle proprietà microstrutturali, chimico-fisiche di materiali inorganici; determinazioni quantitative della composizione mineralogica di materiali naturali e delle proprietà tecniche dei materiali litici" Laboratory funds, DiSTAV, University of Genoa, Italy.

Acknowledgments: The authors acknowledge the availability of the Italian Ministry of Cultural Heritage through the Superintendence of Archaeology, Fine Arts and Landscape for the metropolitan city of Genoa and the provinces of Imperia, La Spezia and Savona. We thank L. Negretti for her support during the SEM-EDS analysis. The research was financially supported by the "Analisi delle proprietà microstrutturali, chimico-fisiche di materiali 
inorganici; determinazioni quantitative della composizione mineralogica di materiali naturali e delle proprietà tecniche dei materiali litici" Laboratory funds, DiSTAV, University of Genoa.

Conflicts of Interest: The authors declare no conflict of interest.

\section{References}

1. Greif, A. On the Political Foundations of the Late Medieval Commercial Revolution: Genoa During the Twelfth and Thirteenth Centuries. J. Econ. Hist. 1994, 54, 271-287. [CrossRef]

2. Airaldi, G. Storia della Liguria. Dal 643 al 1492; Marietti: Genova, Italy, 1900; Volume II.

3. Di Fabio, C. Giovanni Pisano: Margherita di Brabante. In Giovanni Pisano. La Tecnica E Il Genio; Museo di Sant'Agostino: Genova, Italy, 2001.

4. Roascio, S.; Zucchiatti, A.; Prati, P.; Cagnana, A. Study of the pigments in medieval polychrome architectural elements of "Veneto-Byzantine" style. J. Cult. Herit. 2002, 3, 289-297. [CrossRef]

5. De Negri, T.O. Storia di Genova; Aldo Martello Editore: Milano, Italy, 1974.

6. Rossini, G. San Francesco di Castelletto: Dagli inizi alle demolizioni ottocentesche. In Giovanni Pisano a Genova; Seidel, M., Ed.; SAGEP: Genova, Italy, 1987; pp. 229-264.

7. Poleggi, E. Genova. Una civiltà di Palazzi; Silvana Editoriale: Milano, Italy, 2002.

8. Di Fabio, C. San Francesco di Castelletto da Chiesa a giardino. In I Musei di Strada Nuova a Genova:Palazzo Rosso, Palazzo Bianco e Palazzo Tursi; Umberto Allemandi \& Co.: Genova, Italy, 2004.

9. Traverso, A.; Rossini, G.; Traversone, P.C.; Genova, V. San Francesco in Castelletto: Le indagini 2013. Archeol. Liguria 2015, V, 75-95.

10. Klapisch-Zuber, C. Carrara E I Maestri Del Marmo (1300-1600); Deputazione di Storia Patria per le antiche provincie modenesi: Massa, Italy, 1973.

11. Scrivano, S.; Gaggero, L.; Volpe, E. Paint relics on Middle Age building stones as proxies of commercial routes and artistic exchanges: A multi-analytical investigation. Minerals 2019. Submitted.

12. Antonelli, F.; Lazzarini, L. An updated petrographic and isotopic reference database for white marbles used in antiquity. Rend. Lincei 2015, 26, 399-413. [CrossRef]

13. Poretti, G.; Brilli, M.; De Vito, C.; Conte, A.M.; Borghi, A.; Günther, D.; Zanetti, A. New considerations on trace elements for quarry provenance investigation of ancient white marbles. J. Cult. Herit. 2017, 28, 16-26. [CrossRef]

14. Capedri, S.; Venturelli, G. Accessory minerals as tracers in the provenancing of archaeological marbles, used in combination with isotopic and petrographic data. Archaeometry 2004, 46, 517-536. [CrossRef]

15. Belfiore, C.M.; Ricca, M.; La Russa, M.F.; Ruffolo, S.A.; Galli, G.; Barca, D.; Malagodi, M.; Vallefuoco, M.; Sprovieri, M.; Pezzino, A. Provenance study of building and statuary marbles from the Roman archaeological site of "Villa dei Quintili" (Rome, Italy). Ital. J. Geosci. 2016, 135, 236-249. [CrossRef]

16. Ricca, M.; La Russa, M.F.; Ruffolo, S.A.; Davidde, B.; Barca, D.; Crisci, G.M. Mosaic marble tesserae from the underwater archaeological site of Baia (Naples, Italy): Determination of the provenance. Eur. J. Mineral. 2014, 26, 323-331. [CrossRef]

17. Lazzarini, L. Archaeometric aspects of white and coloured marbles used in antiquity: The state of the art. Period. di Mineral. 2004, 73, 113-125.

18. Lazzarini, L. Pietre e Marmi antichi. Natura, Caratterizzazione, Origine, Storia d'Uso, Diffusione, Collezionismo; CEDAM: Padoya, Italy, 2004.

19. Di Fabio, C. Architettura polimaterica e accorgimenti percettivi, policromia della scultura e uso delle immagini nella cattedrale di Genova agli inizi del XIII secolo. In Proceedings of the Medioevo l'Europa delle Cattedrali, Parma, Italy, 19-23 September 2006.

(C) 2019 by the authors. Licensee MDPI, Basel, Switzerland. This article is an open access article distributed under the terms and conditions of the Creative Commons Attribution (CC BY) license (http://creativecommons.org/licenses/by/4.0/). 